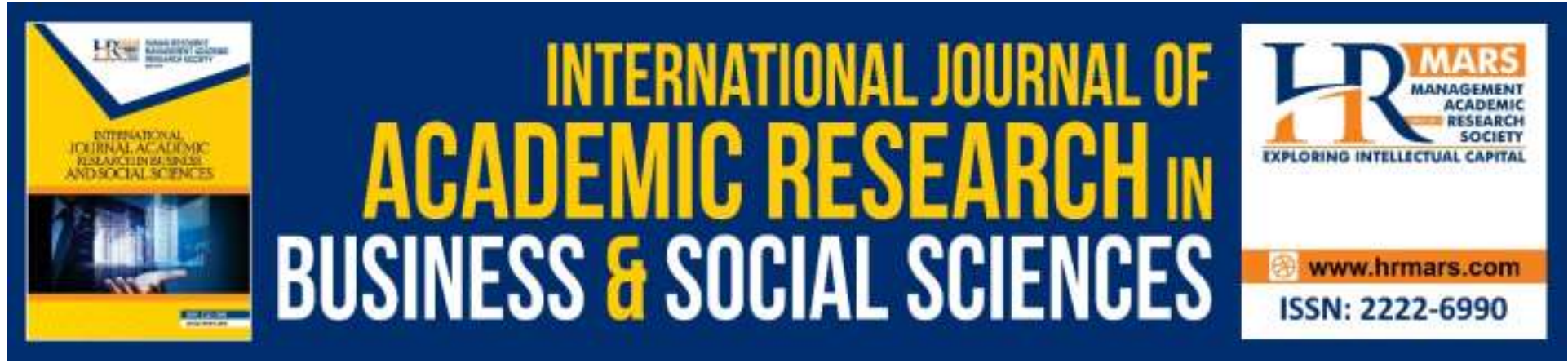

\title{
Teachers' Perception of Students' Knowledge, Skills and Attitudes on Global Citizenship
}

Hamidah Yusof, Mohd Asri Mohd Noor, Norasibah Abdul Jalil, Mahaliza Mansor, Jamal Nordin

To Link this Article: http://dx.doi.org/10.6007/IJARBSS/v9-i9/6278

DOI: $10.6007 /$ IJARBSS/v9-i9/6278

Received: 08 June 2019, Revised: 16 July 2019, Accepted: 24 August 2019

Published Online: 08 September 2019

In-Text Citation: (Yusof, Noor, Jalil, Mansor, \& Nordin, 2019)

To Cite this Article: Yusof, H., Noor, M. A. M., Jalil, N. A., Mansor, M., \& Nordin, J. (2019). Teachers' Perception of Students' Knowledge, Skills and Attitudes on Global Citizenship. International Journal of Academic Research in Business and Social Sciences, 9(9), 153-164.

\section{Copyright: (C) 2019 The Author(s)}

Published by Human Resource Management Academic Research Society (www.hrmars.com)

This article is published under the Creative Commons Attribution (CC BY 4.0) license. Anyone may reproduce, distribute, translate and create derivative works of this article (for both commercial and non-commercial purposes), subject to full attribution to the original publication and authors. The full terms of this license may be seen at: http://creativecommons.org/licences/by/4.0/legalcode

\section{Vol. 9, No. 9, 2019, Pg. 153 - 164}

Full Terms \& Conditions of access and use can be found at http://hrmars.com/index.php/pages/detail/publication-ethics 


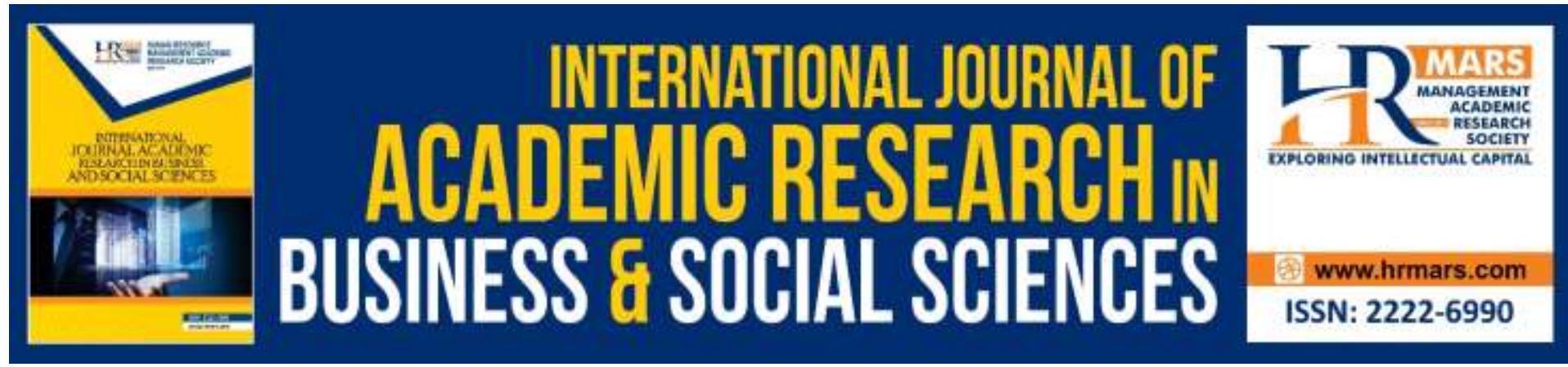

\title{
Teachers' Perception of Students' Knowledge, Skills and Attitudes on Global Citizenship
}

\author{
Hamidah Yusof, Mohd Asri Mohd Noor, Norasibah Abdul Jalil, \\ Mahaliza Mansor, Jamal Nordin \\ Faculty of Management and Economics, Universiti Pendidikan Sultan Idris \\ Email: hamidah.yusof@fpe.upsi.edu.my,mohd.asri@fpe.upsi.edu.my, \\ norasibah@fpe.upsi.edu.my, mahaliza@fpe.upsi.edu.my, jamal@fpe.upsi.edu.my
}

\begin{abstract}
The purpose of this study is to identify teachers' view on students' degree of knowledge, skills, and attitudes relating to global citizenship issues. A total of 87 primary and secondary school teachers from several states were selected. This study used questionnaires to collect data. The data were analyzed using descriptive statistics. The findings showed that the level of knowledge is relatively high, while students' degree of skills and attitudes about global citizenship are relatively moderate. In addition, at the primary school level, the mean scores are relatively low compared to the secondary school level. The findings also showed that students' knowledge, skills, and attitudes in secondary schools are higher than in primary schools. This study proposed a more structured global citizenship education to be embedded in the schools' education structure and as a guideline that can be followed by all teachers to produce students who are willing to become aspiring global citizens for national and global well-being.
\end{abstract}

Keywords: Knowledge, Skills, Attitudes, Global Citizenship Education, Primary School, Secondary School

\section{Introduction}

In a rapidly developing world, there are remarkable changes that take place in technology, politics, education, and economic sectors. Globalization affects citizens through various changes in living standard, politics, social, socioeconomics, education, culture, and so forth. The development of technology and information creates a world community as a more humane and pragmatic society despite the potential negative impacts that have widely discussed. In other words, the influence of globalization has the potential to develop a positive or negative global citizen from the aspect of self-confidence, the norm of life, the behavior, and the pure values apart from the economic and commercial factors (Banks, 2008: 132).

The government must manage the development of globalization that affects the development of global citizens well, including the education system which used as the 
channel that aimed at producing a professionally global citizen in society and state. Focusing on its huge benefit, Global Citizenship Education should be emphasized among primary and secondary students to ensure they are well prepared with appropriate knowledge, skills, and attitudes. Zamroni (cited by Sutrajat, 2013) argues that citizenship education is an education on democracy to the younger generation, which guarantees the rights of citizens. Quality citizenship education can build democracy and form a prosperous and productive society. Its also empowers individuals to give them the right to speak, opportunity to unleash their potential, gives way to self-perfection, and extend their insights and thoughts beyond borders. An individual can build self-confidence in dealing with their lives, enjoying the facilities in the environment and understanding themselves through this education. It also functions as a catalyst for living well by leading the individual towards steady economic resources, self-control capabilities, and social relations stability. The crisis factor experienced by a country will undoubtedly affect the younger generation. Muhammad Syaifudin and Agus Satmoko state, the younger generation that is deeply rooted to the state will surely be the next generation of nations to lead and bring change to their nation towards greater success (cited by Sutrisno, 2018). Nurturing citizenship education may lessen the negative impact that spills over on them.

The younger generation mainly primary and secondary school students should study citizenship education. Students would be real, critical, fair, democratic, and responsible person through this education. The degree of knowledge, skills, and attitudes of global citizenship education among primary and secondary students can be traced through the perceptions of teachers at school. Awareness of the importance of global citizenship education helps students to become people who know the rights and obligations to their beloved country and the world.

Measuring a teacher's perception of global citizenship is essential because they are the ones who are going to implement the policy (Seo, 2016). The literature review conducted on global citizenship education mostly emphasized students' perceptions, and very few studies emphasize this education from the teacher perceptions'. Considerable research has also been done to study global citizenship education (Morais \& Ogden, 2011; Seo, 2016) but it was not easy to find research focused on teachers in ASEAN Countries and their perception of global citizenship education (Seo, 2016; Jeong, 2017). Most of the current research on global citizenship education has been conducted based on the Western Countries (Davies, 2006; O'Sullivan \& Pashby, 2008; Dill,2013; Seo, 2016), which significantly failed to represent global citizenship (Jeong, 2017). Most studies of GCE are based on Western values; there a dire need to study GCE based on Malaysia context. Therefore, this study attempts to examine the perceptions of teachers by the level of knowledge, the skills of students' and their attitudes on global citizenship based on the Malaysia context.

\section{Literature Review}

Morais and Ogden (2011) state that citizenship that develops into global citizenship is a multidimensional construct; that relies on the interconnectedness of the dimensions of social responsibility, global competence, and citizen involvement globally. Each citizen needs to have the right knowledge, skills, and attitudes to ensure they become a global citizen who is aware of current developments. Knowledge is a personal experience which guides us to do 
the right thing (Ainon \& Abdullah, 2003). Knowledge also resulted from a cognitive process that involves experiences, formal and informal education as a valuable input to the individual (Kamaruddin, 2010).

Skills are difficult to measure, but it can be seen through the level of individual domination when they do something. Attitudes can be shown in a positive or negative response depending on the person's tendency towards something or condition (Sharifah Alawiyah, 1985). In this study, knowledge, skills, and attitudes are measured in seven elements namely human rights, sustainable development, climate change, peace and prosperity, global citizenship, gender equality, health and well-being (UNESCO, 2017).

Harlida and Asiah (2008) describe humanitarian rights as a necessary right and decent freedom for every person as human beings. These rights will guarantee the dignity of human beings and promote human goodness. Sustainable development means development that meets the current needs without destroying or hacking the needs of future generations (Keeble, 1987).

Climate change and global warming are situations that are increasingly critical and unstoppable. According to Daniel Murdiyarso (2003), the occurrence of climate change is the product of human activity. This activity will produce a greenhouse effect which will cause global warming.

International security is an action taken by nations and international organizations such as The United Nations united for the sake of mutual security and defense (Owen, 2004). According to Collins (2003), security is a necessity for maintaining the resilience of a nation through economic power, defense, political power, and diplomatic expertise.

All elements discussed previously are essential to the human quality of living. Brues and Richardson (1989) stressed that to create a healthy lifestyle; individuals need to know about health and awareness of behaviors on balanced nutrition. Individuals and communities also need to practice and evaluate their physical health and fitness regularly. They need to be aware that a clean and safe environment is necessary to stimulate a healthy lifestyle.

Global citizenship education helps to develop universal citizen concept when the learning process is oriented towards the development of attitudes, knowledge, and skills in solving various problems, conflicts, and global issues. Global citizenship education should be emphasized at primary and secondary schools as it is a way to raise the cognitive, affective and psychometric of the student at a maximum level. The global civic education can be used for moral formation, which aimed at displaying attitudes reflecting appreciation, understanding, and experience for themselves as well as for the community. Besides, having a high commitment is guaranteed by a positive attitude and a sound understanding. Moreover, one can think critically, rationally, and creatively and instill the spirit of patriotism and love the country (Syarbaini cited by Sutrisno, 2018).

The competence of global citizens is a trait of citizens in overcoming the challenges faced by global (Cogan \& Derricot, 2000). The characterized character will make the student as an ideal 
person by having the appropriate knowledge, skills and values. Albert Bandura believes that all human beings are clean and pure from mistakes; the cause of their behavior formation is from the aspect of the environment. Furthermore, human behavior based on one's experience of learning from the environment. For example, the frequent disciplinary mistakes by students, which resulted in moral collapse stems from various problems around them (Zainal, 2009).

According to Rapoport (2008), the concept of a global vision of a citizen does not refer to the citizenship status owned by each individual and the citizenship change into a global context. Instead, it focuses on the role played in the global context. It emphasizes the existence of citizens in the context of universal life. The formation of global citizenship education is seen best to implement at an early stage of schooling, specifically the primary and secondary schools level. The fun learning process should be inculcating the values of the privilege of global citizenship education in terms of knowledge, skills, and attitudes.

According to social studies teacher at Hickory High School; global citizens are someone who is rooted in their national identity, have higher awareness in respecting cultural diversity, tolerance towards confidence, trust and view various global issues (Dill, 2013). Therefore, teaching and learning process should help students to become real human beings in various quality aspects of life, but in reality, teachers at school still faced multiple challenges in instilling the noble values in each student. The students do not appreciate the aspects contained in global citizenship education even though the teachers teach them these global values in the classroom. Moreover, students are not concerned about the knowledge, skills, and attitudes in the citizenship education that they learned at school.

Oxfam (2015) states that global citizenship is a way of understanding how the world works, links between our own lives and those people across the globe. Thus, global citizenship education is a way to know how the world works and the relationship between our life and others around the world. The challenges and obstacles to teach citizenship education in our subjects are indirectly due to the Malaysian exam-oriented education system. Students indirectly give their preference to the subjects that they need to take in a formal exam. All of this affects the level of knowledge, skills, and attitudes of global citizenship education among students in both primary and secondary schools. Therefore, a study needs to be carried out to identify the degree of students' knowledge, skill and attitude based on this issue. The result obtained will give a significant impact on planning a preventive action in the near future. The strong urge to embedding global citizenship education in the education structure is a critical need in the education system as part of the effort to shape up our future generation.

\section{Methodology}

This study is critical as it recognizes the level of knowledge, skills, and attitudes of global citizenship education among primary and secondary students through the perception of teachers. The study involved 87 teachers from several states. The teachers involved are responsible for teaching primary school students in Year 4, Year 5, Year 6, and teachers teaching Form 1 to Form 5 in secondary schools. 
The research instrument for this study consist of a set of questionnaires that measure the constructs of knowledge, skills, and attitudes towards the elements of global citizenship education. This questionnaire consists of two parts. Part A represents items from the demographic background of the respondents, such as gender, teaching subjects, years of teaching, and grade taught. Part B is related to items that contain constructs of knowledge, skills, and attitudes. Each of these constructs divided into seven key elements in this study, namely human rights, sustainable development, climate change, peace and prosperity, global citizenship, gender equality, and health and well-being. The data were analyzed using descriptive statistics. Score interpretation based on 1.0-2.33 (low), 2.34-3.67 (moderate), and 3.68-5.0 (high).

\section{The Findings}

The findings showed that teachers view students as having a high level of knowledge, but their skills and attitudes are moderate to global citizenship education (Table 1). Although students know, they fail to portray through their skills and behaviors. Students show the highest mean score in the "health and well-being" elements, followed by "peace and prosperity," "sustainable development," "climate change, gender equality," "global citizenship" and "human rights." While students show the highest level of skill for "peace and prosperity," followed by "health and well-being," "climate change," "sustainable development," "gender equality," "human rights," and global citizenship." In addition, students show the highest mean of "peace and prosperity," "health and wellbeing," "climate change," "sustainable development," "gender equality" and "human rights," and "global citizenship" for attitude. In conclusion, the findings show that elements of human rights and global citizenship need to be further emphasized by teachers in educating global citizenship.

Table 1

Knowledge, Skills and Student Levels on Global Citizenship Education

\begin{tabular}{lcccccc}
\hline \multirow{2}{*}{$\begin{array}{l}\text { Global Citizenship } \\
\text { Education }\end{array}$} & \multicolumn{2}{c}{ Knowledge } & \multicolumn{2}{c}{ Skills } & \multicolumn{2}{c}{ Attitude } \\
\cline { 2 - 7 } & Mean & $\begin{array}{c}\text { Std. } \\
\text { Deviation }\end{array}$ & Mean & $\begin{array}{c}\text { Std. } \\
\text { Deviation }\end{array}$ & $\begin{array}{c}\text { Mea } \\
\mathbf{n}\end{array}$ & $\begin{array}{c}\text { Std. } \\
\text { Deviation }\end{array}$ \\
\hline Human Rights & 2.61 & .950 & 2.54 & .929 & 2.53 & .962 \\
Sustainable Development & 2.81 & .929 & 2.73 & .923 & 2.63 & .965 \\
Climate Change & 2.76 & .929 & 2.68 & .923 & 2.64 & .923 \\
Peace and Prosperity & 2.87 & .923 & 2.86 & .912 & 2.82 & .893 \\
Global Citizenship & 2.64 & .895 & 2.52 & .997 & 2.45 & .988 \\
Gender Equality & 2.71 & .920 & 2.57 & .985 & 2.54 & .983 \\
Health and Wellbeing & 2.92 & .873 & 2.82 & .893 & 2.76 & .906 \\
Overall & 2.76 & .856 & 2.67 & .867 & 2.63 & .886 \\
\hline
\end{tabular}


Table 2

Students' Knowledge, Skills and Attitude at Primary and Secondary Schools

\begin{tabular}{lcccc}
\hline \multirow{2}{*}{ Global Citizenship Education } & \multicolumn{2}{c}{ Primary School } & \multicolumn{2}{c}{ Secondary School } \\
\cline { 2 - 5 } & Mean & Std. Deviation & Mean & Std. Deviation \\
\hline Knowledge & $\mathbf{2 . 6 5}$ & .946 & $\mathbf{3 . 0 3}$ & .516 \\
Human Rights & 2.51 & .925 & 2.85 & .707 \\
Sustainable Development & 2.71 & .935 & 3.04 & .564 \\
Climate Change & 2.65 & .942 & 3.03 & .505 \\
Peace and Prosperity & 2.76 & .993 & 3.12 & .686 \\
Global Citizenship & 2.50 & .966 & 2.97 & .595 \\
Gender Equality & 2.59 & .952 & 2.99 & .608 \\
Health and Wellbeing & 2.81 & .964 & 3.20 & .526 \\
\hline Skills & $\mathbf{2 . 6 0}$ & .967 & $\mathbf{2 . 8 4}$ & .544 \\
Human Rights & 2.49 & .924 & 2.65 & .659 \\
Sustainable Development & 2.66 & .938 & 2.89 & .553 \\
Climate Change & 2.64 & .940 & 2.78 & .564 \\
Peace and Prosperity & 2.79 & .976 & 3.01 & .733 \\
Global Citizenship & 2.36 & .966 & 2.88 & .700 \\
Gender Equality & 2.47 & .981 & 2.80 & .669 \\
Health and Wellbeing & 2.79 & .979 & 2.89 & .659 \\
\hline Attitude & $\mathbf{2 . 5 6}$ & .975 & $\mathbf{2 . 7 8}$ & .619 \\
Human Rights & 2.49 & .913 & 2.61 & .842 \\
Sustainable Development & 2.57 & .981 & 2.77 & .608 \\
Climate Change & 2.60 & .942 & 2.75 & .559 \\
Peace and Prosperity & 2.76 & .959 & 2.97 & .711 \\
Global Citizenship & 2.31 & .989 & 2.79 & .586 \\
Gender Equality & 2.44 & .967 & 2.79 & .710 \\
Health and Wellbeing & 2.75 & .997 & 2.80 & .660 \\
\hline
\end{tabular}


The overall findings showed in Table 2. The table shows the mean score values of knowledge, skills, and attitudes towards the items of education of global citizenship in secondary schools is relatively higher than in primary schools. At primary level, the lowest mean scores figured in the "human rights" (knowledge), "global Citizenship" (skill and attitude) items. At the secondary level, the "human rights" (Knowledge, Skill, and Attitude) item score the lowest.

\section{Discussion}

The overall findings showed that the degree of students' knowledge, skills, and attitudes on global citizenship education are still at moderate levels. The result is relatively reliable as currently, there no specific curriculum available for this subject. The concept of global citizenship education in Malaysia is integrated into other subjects such as civics, geography, history and moral studies (Jeong, 2017). Whereas other countries, such as the United Kingdom, had already provided a module with clear guidelines for all the teachers to carry out this education in their school (Oxfam, 2015). Moreover, UNESCO (2015) had provided clear topics and objectives that can be used to teach this subject or incorporate them into other subjects.

The findings also showed that the mean score values for skills are relatively moderate. It is a well-accepted fact that; the incorporation of specific skills in the subjects taught, allows students to study in-depth on citizenship education. The introduction of this subject at an early stage of education, which is at a primary school will give a significant impact on the development of this subject. Students will learn the basics of knowledge, skills, and attitudes about global citizenship education in their early stage of life and continue it in secondary education later. However, there is a challenge in the implementation of Global Citizenship Education (GCE) as a single course at schools. Myers (2016, p.11) said, "Global Citizenship Education (GCE) is at a critical juncture in its development as an academic field. GCE is not a unified field of inquiry despite its' convergence of interest. A common critique of GCE is fundamentally political from factions who see schools as serving nationalist interests, an argument that is becoming increasingly difficult to justify. However, scholars in the field also need to face up to the challenges of building the field and helping it to advance a democratic vision for future scholarship within the constraints of public schooling. "

Teachers also viewed the degree of students attitudes towards global citizenship education is relatively moderate compared to the knowledge and skills; attitudes mean scores is the lowest. This result showed that even though students have the knowledge and skills, there are no guarantees that students can show positive attitudes towards global citizenship elements. Banks (2008: p.135) suggests that there needs to be a repetition concept in citizenship education in the 21st century to effectively educate students into becoming global citizens. Citizenship education is intended to produce learning related to various elements. The combination of these elements in education can give students an awareness of the roles, rights, and responsibilities within the family, community, nation, and global environment to create a united, patriotic and prosperous community of citizens in the nations and globally. From these findings and discussions, there are several suggestions made to help improve the level of knowledge, skills, and attitudes of global citizenship among primary and secondary students in Malaysia. Firstly, teachers as facilitators will make the learning process more effective if it conceptualized in a more relaxed discussions format than the traditional learning 
format. It prepares students to listen to their teacher to gain more knowledge. The teachers will act as an individual who has the skills to create conditions for facilitating, guiding and promoting student self-learning. According to Gregory (in Fazian, 2014), the teacher as a facilitator acts as a "guide" for students to work in groups and helps students to solve problems. According to Fazian (2014), teachers as facilitators are also capable of promoting high-order thinking skills in students who are now highly-regarded in teaching and learning activities. It is due to the role of the teachers as the primary source of knowledge acquired by the students and their ability to transform the knowledge into a skill. Moreover, the role of teachers as facilitators will also make the learning process more fun as students are not only focused on listening to all the information, but they also can produce relevant ideas related to the topics discussed. It shows that the learning process will be more effective if it happens in two-way rather than a one-way process.

The return of the Civics and Citizenship Education (CCE) subjects is one of the wise suggestions in the effort to embed elements of global citizenship education in primary and secondary school students; as a particular subject in the Malaysia Education Blueprint 2013-2025. CCE plays a vital role in the national curriculum of high school to produce patriotic and responsible pupils as Malaysians. It is a subject that has the purpose of linking students to the community, roles, rights and responsibilities as citizens. Besides, it also can foster values to form individuals who can contribute positively towards the society and nation. Students will acquire more moral values and civics knowledge, skills and values through the interactive and student-centered in teaching and learning of this subject. Therefore, it will directly improve their knowledge, skills and attitude. Teachers only need to focus on the objectives of each topic in the CCE to embed the elements of global citizenship in each student.

The elements in global citizenship education need to embed in every relevant subject taught at school. As an example, the elements of human rights, humanitarian development, gender equality, peace and prosperity are applied in the subjects of History, Moral Education and Islamic Education. It is due to the objectives of these subjects that are related to the concept of human rights, peace, and prosperity taught in every religion. The element of climate change needs to embed in a Science subject as the syllabus itself has a relationship with nature, while the elements of wellness and health can be absorbed in the Physical Education subject. These implementations will make all of these subjects become a core subject in school. Therefore, students need to emphasize more on these subjects seriously to become a healthy and prosperous citizen.

\section{Conclusion}

Research on global citizenship education and teachers' perception based on students knowledge, skills and values in Malaysia is still at an early stage. Study and discussion of global citizenship education are essential nowadays as humanity faces the challenges of the 21st century (Yemini, 2017). Gibson and Reysen's (2013) indicated that teachers perceptions of global citizenship and their worldwide had affected the outcome of global citizenship education. The result of this study reveals that teachers' perception of students knowledge, skills and values in GCE are still at a moderate level. It means that students failed to see the importance of GCE as a crucial subject that they need to study. Even though they have enough knowledge on this subject, they were unable to show it in their skills and attitude. The 
outcome of this study also showed that secondary students have a slightly higher level in knowledge, skills and values compared to primary students.

This research makes a significant contribution to international comparative education and the GCE literature by examining the teachers' perceptions towards students knowledge, skills and attitude to the subject. While most of studies have examined the GCE through students perspective (Çakmak, Bulut \& Taskiran, 2016; Schutte, Kamans, Wolfensberger \& Veugelers, 2017), this study shows different views to the implementation of the GCE, which is from the teachers perspective. This study also provides empirical evidence to the level of teachers' perceptions based on their students' knowledge, skills and attitudes towards the subject. It also reveals the empirical evidence on the comparison between primary and secondary students in knowledge, skills and attitude towards GCE. Furthermore, it measures teachers perceptions on every element in GCE subjects based on students' knowledge, skills and attitude towards the subject. This research also shed some light on the theoretical discussion of different implementation on GCE elements worldwide. Moreover, it shows evidence on the implementation of GCE in Malaysia context.

For further studies, it suggests that a comparison study of the implementation and the effectiveness of global citizenship education between Malaysia and other countries. This study also should be extended by involving more teachers to obtain more comprehensive research findings. Attention should be directed to focus on global citizenship values.

\section{Acknowledgment}

Acknowledgment addressed to the Sultan Idris Education University, which funded this study through the University Research Grant (2018-0223-107-01).

\section{Corresponding Author}

Dayang Rafidah Syariff M.Fuad, Faculty of Educational Management, Universiti Pendidikan Sultan Idris, 35900 Tanjung Malim, Perak, Malaysia.

Email: dgrafidah@gmail.com

\section{References}

Mohd, A., \& Hassan, A. (2003). Belajar Berfikir. Bentong: PTS Publications \& Distributors, Sdn. Bhd.

Banks, J. A. (2008). Diversity, group identity, and citizenship education in a global age. Educational Researcher, 37(3), 129-139. DOI: 10.3102/0013189X08317501

Brues, C. \& Richardson, G. (1989). Decision for health, 2nd. Ed. Wm.C.Brown: Dubuque, lowa.

Çakmak, Z. Bulut, B. \& Taskiran C. (2016). Global Citizenship Perceptions of Students in Different Cultures. International Journal of Learning and Teaching, 2 (1), 48-52.

Cogan, J. J. \& Derricott, R. (2000). Citizenship for the 21st century: An international perspective on education. London, England: Kogan Page.

Collins, H. (2003). Discrimination, equality and social inclusion. Modern Law Review, 66(1), 16-43. DOI:10.1111/1468-2230.6601002

Murdiyarso, D. (2003). Pemanasan Global dan Perubahan Iklim: Risiko masyarakat manusia dan kesan kepada manusia. Retrieved from https://www.researchgate.net/profile/Daniel_Murdiyarso 
Davies, L. (2006). Global citizenship: abstraction or framework for action? Educational Review, 58(1), 5-25. https://doi.org/10.1080/00131910500352523

Dill, J. S. (2013). The longings and limits of global citizenship education: The moral pedagogy of schooling in a cosmopolitan age. New York, NY: Routledge.

Mohamad, A. (2014). Peranan guru sebagai fasilitator pembelajaran berdasarkan masalah (PBM) dalam mata pelajaran sains. Masters thesis, Universiti Teknologi Malaysia, Faculty of Education.

Gibson, S. \& Reysen, S. (2013). Representations of global citizenship in a school environment. International Journal of Education Research, 8(1), 116-128.

Wahab, A. H. \& Bidin, A. (2008). Akta 597: Satu perkembangan hak asasi manusia di Malaysia. Retrieved from HTTP:// repo.uum.edu.my /447/1/ Harlida_Abdul_Wahab.pdf

Jeong, B. (2017). Teachers Perception on Global Citizenship Education in ASEAN Countries (Master Thesis). Retrieved from https://snukr.academia.edu/BeccaBitnaJeong.

Ismail, A. (2010). Pengetahuan, kemahiran pelaksanaan dan sikap guru kimia terhadap kaedah pembelajaran koperatif. Master Thesis. Universiti Kebangsaan Malaysia.

Keeble, B. R. (1987). The Brundtland Commission: Environment and development to the year 2000. Medicine and War, 3(4), 207-210.

DOI:10.1080/07488008708408769

Morais, D. B. \& Ogden, A. C. (2011). Initial Development and Validation of the Global Citizenship Scale. Journal of Studies in International Education, 15(5), 445-446.

Myers, J. P. (2016). Charting a democratic course for global citizenship education: Research directions and current challenges. Education Policy Analysis Archives, 24(55), 1-19. http://dx.doi.org/10.14507/epaa.24.2174

O'Sullivan, M., \& Pashby, K. (2008). Citizenship education in the era of globalization: Canadian perspectives / edited by Michael O'Sullivan and Karen Pashby. Rotterdam: Sense Publishers.

Owen, T. (2004). Human Security - Conflict, Critique, and Consensus: Colloquium Remarks and a Proposal for a Threshold-Based Definition. Security Dialogue, 35(3), 373-387. DOI:10.1177/0967010604047555

Oxfam. (2015). Education for global citizenship: A guide for school. Oxford: Oxfam Development Education. Retrieved from

https://www.oxfam.org.uk/education/resources/education-for-global-citizenship-aguide-for-schools.

Rapport, A. (2008). A forgotten concept: Global citizenship education and state social studies standards. The Journal of Social Studies Research, 91-112.

Seo, H. (2016). A Study on Secondary School Teachers' Global Citizenship Type and Perceptions of Global Citizenship Education. (Master Thesis). Seoul National University, Seoul. Retrieved from http://dcollection.snu.ac.kr:80/jsp/common/DcLoOrgPer.jsp?sltemld=00000013676 4

Schutte, I. W., Kamans, E., Wolfensberger, M. V. C., \& Veugelers, W. (2017). Preparing Students for Global Citizenship: The Effects of a Dutch Undergraduate Honors Course. Education Research International. 3459631.

Alsagoff, S. A. (1985). Ilmu pendidikan pedagogi. Kuala Lumpur: Dewan Bahasa dan Pustaka. 
Nyompa, S., Alit, N., Jali, M. F. M., Rostam, K. (2012). Migrasi dan impaknya terhadap aspek sosial dan ekonomi di bandar Makassar, Sulawesi Selatan, Indonesia. Jurnal Perspektif, 4(2), 85-98.

Sutrajat. (2014). Revitalisasi pendidikan multikultural dalam pembelajaran sejarah. Jurnal Pembangunan Pendidikan: Fondasi dan Aplikasi, 2(1), 82-90.

Sutrisno. (2018). Peran pendidikan kewarganegaraan dalam membangun warga negara global. Citizenship Jurnal Pancasila dan Kewarganegaraan, 6(1), 41-51.

UNESCO. (2015). Global citizenship education: Topics and learning objectives. Retrieved from https://unesdoc.unesco.org/ark:/48223/pf0000232993

UNESCO. (2017). Measurement strategy for SDG Target 4.7. http://uis.unesco.org/sites/default/files/documents/gam/4-measurement-strategy-sdg target4.7.pdf

Yemini, M. (2017). Internalization and global citizenship: Policy and practice in education. Cham, $\mathrm{CH}$ : Palgrave Macmillan.

Zainal, K. (2009). Memahami tingkah laku remaja bermasalah dari perspektif teori tingkah laku, humanistik, psikoanalitik \& tret personaliti. Jurnal Pengajian Umum, 9, 43-55. 